\title{
Identification of type $A$ and $B$ isolates of Epstein-Barr virus by polymerase chain reaction
}

\author{
Wolfgang Jilg, Emilia Sieger, Peter Alliger and Hans Wolf \\ Max von Pettenkofer-Institute for Hygiene and Medical \\ Microbiology. University of Munich, Munich, F.R.G.
}

(Accepted 3 August 1990)

\section{Summary}

A method is described for the identification of type $A$ and type $B$ isolates of Epstein-Barr virus (EBV) by means of the polymerase chain reaction. The use of three pairs of primers specific for genomic sequences coding for the two forms of EBV nuclear antigen (EBNA), $2 A$ and $2 B$, and for a DNA sequence from the $B a m Z / B a m R$ region allows the reliable and rapid detection of type $A$ and $B$ viruses in as little as $1000 \mathrm{EBV}$ positive cells.

Epstein-Barr virus (EBV), type $A$ and $B$; Epstein-Barr virus nuclear antigen (EBNA) $2 \mathrm{~A}$ and 2B; Polymerase chain reaction

Two types, A and B, of Epstein-Barr virus (EBV) have been identified which show DNA sequence divergence within the BamHI WYH region of the genome. This region encodes for the Epstein-Barr nuclear antigen 2 (EBNA 2) which accordingly exists as two antigenically different alleles, EBNA 2A and EBNA 2B. Recently, Rowe et al. (1989) showed that the distinction between the two types extends beyond the EBNA 2 gene to the EBNA 3 family of proteins. Whereas type B virus was previously found mainly in equatorial Africa (Zimber et al., 1986) recent findings indicate that this type is also widespread in other

Correspondence to: W. Jilg, Max von Pettenkofer-Institute, Pettenkoferstraße 9a, D-8000 Munich 2. F.R.G. 
regions (Sculley et al., 1988; Sixbey et al., 1989). However, type A and type $\mathrm{B}$ isolates differ in their biological properties as type $\mathrm{B}$ virus has a markedly reduced ability to transform B lymphocytes (Rickinson et al., 1987) and seems to show a different tissue tropism (Sixbey et al., 1989); so far, however, it is unknown whether these two types also possess a different pathogenic potential. Identification of type A and type B isolates is usually accomplished by Southern blot analysis of viral DNA (Zimber et al., 1986; Sixbey et al., 1989) or by immunoblotting of lysates of EBV infected cells with specific antisera (Rickinson et al., 1987). In this paper we are presenting a method of typing EBV by PCR using EBNA 2A and 2B gene specific primer pairs.

Specific primers were synthesized based on the published DNA sequences of Dambaugh et al. (1984) (for EBNA 2A and 2B genes), and of Baer et al. (1984) (for the BamZ and BamR regions).

Sequences of primers (location in the EBV genome):

2A-FS: $5^{\prime}$ TCT TGA TAG GGA TCC GCT AGG ATA $3^{\prime}$ (1842-1865) 2A-CS: $5^{\prime}$ ACC GTG GTT CTG GAC TAT CTG GAT C $3^{\prime}$ (2338-2314)

2B-FS: $5^{\prime}$ ACT GGA TAT GAA TCC CCT GGG CAG $3^{\prime}$ (1769-1792) 2B-CS: $5^{\prime}$ GAG TCC TGT ACT ATC AGA ACT ACA ATG $3^{\prime}$ (2234-2208)

\section{Z-FS: 5' AAT AGA CAG CCC AGT TGA AA 3' (103386-103405)} Z-CS: $5^{\prime}$ GCA GTG CCA TAT CTG ACG TG $3^{\prime}$ (103894-103875)

Cells were suspended (at $5 \times 10^{5}$ cells $/ \mathrm{ml}$ ) in lysis buffer containing $100 \mu \mathrm{g} / \mathrm{ml}$ of freshly added proteinase K, $0.5 \%$ (w/v) NP-40, $50 \mathrm{mM} \mathrm{KCl}, 10 \mathrm{mM}$ Tris- $\mathrm{HCl}$, $\mathrm{pH} 8.3,1.5 \mathrm{mM} \mathrm{MgCl}_{2}$ (Kawasaki, 1990). Samples were incubated for $45 \mathrm{~min}$ at $56^{\circ} \mathrm{C}$, then heated to $95^{\circ} \mathrm{C}$ for $10 \mathrm{~min} ; 20 \mu \mathrm{l}$ were used per assay.

Amplification conditions (in $50 \mu \mathrm{l}$ assays) were: Taq polymerase (Perkin Elmer Cetus, Überlingen, F.R.G.) 1.25 U/assay; dNTPs (Boehringer, Mannheim,

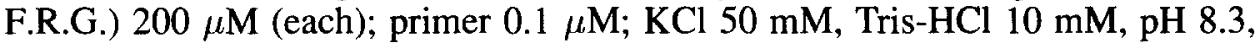
$\mathrm{MgCl}_{2} 1.5 \mathrm{mM}$, gelatin $0.1 \%(\mathrm{w} / \mathrm{v})$. Samples were processed for 50 cycles in a Bio-Med reaction cycler (Bio-Med, Theres, FRG) with denaturation at $94^{\circ} \mathrm{C}$ for $30 \mathrm{sec}$, annealing at $55^{\circ} \mathrm{C}$ for $1 \mathrm{~min}$, extension at $72^{\circ} \mathrm{C}$ for $3 \mathrm{~min}$. Amplified sequences were visualized on a $2 \%$ agarose gel using standard conditions.

Fig. 1 shows the EBV type B containing cell line AG876, the type A line B95-8 and the EBV negative line BJAB tested for the presence of EBNA 2A and EBNA 2B sequences. A control reaction was performed with a primer pair $(\mathrm{Z})$ derived from a highly conserved region in the $B a m Z$ and Bam Regments of the EBV genome. Strong signals were seen indicating the presence of the amplified EBNA 2A gene sequence of 497 bp or the EBNA 2B sequence (466 bp) exclusively in the type A or type B infected cells, respectively. As expected, both cell lines were found positive for the $\mathrm{Z} / \mathrm{R}$ sequence. Visible bands were still observed even when only one tenth of the cellular material (an equivalent of 1000 cells per assay) was analysed (not shown). Testing several EBV positive 


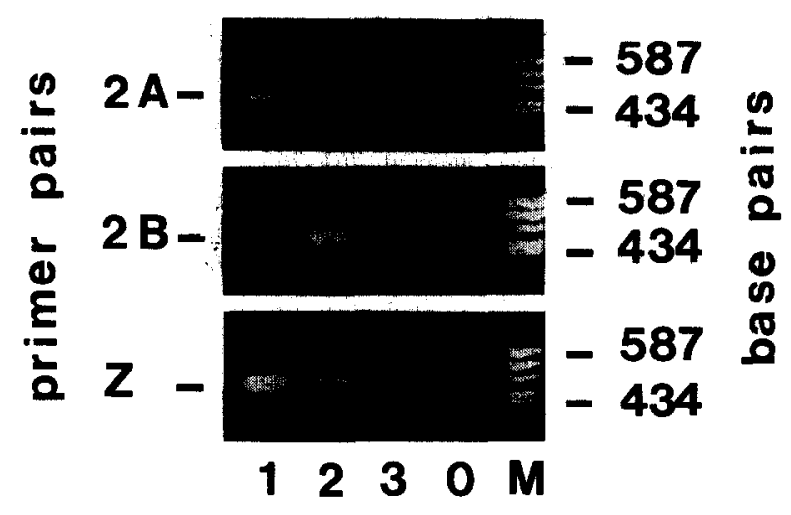

Fig. 1. PCR typing of EBV transformed cell lines for the presence of type $A$ and type $B$ isolates of EBV. EBNA 2A and EBNA 2B gene specific sequences were amplified by using primer pairs $2 \mathrm{~A}$ and $2 \mathrm{~B}$, respectively; primer pair $\mathrm{Z}$ allows the amplification of a conserved sequence common to all EBV strains. 1, B95-8 (type A positive cell line); 2, AG876 (type B positive cell line); 3, BJAB (EBV negative cell line); 0 , reagent control (without added templates); $\mathrm{M}$, length standards.

cell lines, all reacting with the $\mathrm{Z}$ primers, we found the type $\mathrm{B}$ positive cell line Jijoye reactive only with the $2 B$ primers, six EBV transformed lymphoblastoid cell lines established from healthy EBV positive donors showed exclusively the 2A sequence, whereas the P3HR-1 line lacking the EBNA 2 gene was negative for both. Thus, the method described allows the reliable and rapid detection of type $A$ and $B$ viruses in as little as 1000 cells.

\section{Acknowledgements}

We thank Holger Fließbach for synthesizing the oligonucleotides. This work was supported by a grant from the Deutsche Forschungsgemeinschaft, SFB 217, Projekt B 3.

\section{References}

Baer, R., Bankier, A.T., Biggin, M.D., Deininger, P.L., Farrel P.J., Gibson, T.J., Hatful, G., Hudson, G.S., Satchwell, S.C., Seguin, C., Tuffnell, P.S. and Barrell, B.G. (1984) DNA sequence and expression of the B95-8 Epstein-Barr virus genome. Nature 310, 207-211.

Dambaugh, T., Hennessy, K., Chamnankit, L. and Kieff, E. (1984) U2 region of Epstein-Barr virus DNA may encode Epstein-Barr nuclear antigen 2. Proc. Natl. Acad. Sci. USA 81, 7632-7636.

Kawasaki, E.S. (1990) Sample preparation from blood, cells, and other fluids. In: M.A. Innis, D.H. Gelfand, J.J. Sninsky and T.J. White (Eds), PCR Protocols. Academic Press, San Diego, pp. 146-152.

Rickinson, A.B., Young, L.S. and Rowe, M. (1987) Influence of the Epstein-Barr virus nuclear antigen EBNA 2 on the growth phenotype of virus-transformed B cells. J. Virol. 61, 1310-1317.

Rowe, M., Young, L.S., Cadwallader, K., Petti, L., Kieff, E., Rickinson, A.B. (1989) Distinction between Epstein-Barr virus type A (EBNA 2A) and type B (EBNA 2B) isolates extends to the EBNA 3 family of nuclear proteins. J. Virol. 63, 1031-1039. 
Sculley, T.B., Cross, S.M., Borrow, P. and Cooper, D.A. (1988) Prevalence of antibodies to EpsteinBarr virus nuclear antigen $2 B$ in persons infected with the human immunodeficiency virus. J. Infect. Dis. $158,186-192$.

Sixbey, J.W., Shirley, P., Chesney, P.J., Buntin, D.M. and Resnick, L. (1989) Detection of a second widespread strain of Epstein-Barr virus. Lancet ii, 761-765.

Zimber, U., Adldinger, H.K., Lenoir, G.M., Vuillaume, M., von Knebel-Doeberitz, M., Laux, G., Desgranges, C., Wittman, P., Freese, U.K., Schneider, U. and Bornkamm, G.W. (1986) Geographical prevalence of two Epstein-Barr virus types. Virology 154, 56-66. 